This is a post-peer-review, pre-copy edited version of a chapter published in Gavin Brown, Anna Feigenbaum, Fabian Frenzel, Patrick McCurdy (eds), Protest camps in international context: Spaces, infrastructures and media of resistance, Policy Press, 2017. Details of the definitive published version and how to purchase it are available online at:

https://policypress.co.uk/protest-camps-in-international-context

*Please do not cite from this unpublished version*

\title{
Carry on camping? The British Camp for Climate Action as a political refrain
}

Bertie Russell, Raphael Schlembach \& Ben Lear

\begin{abstract}
The chapter engages with the notion of 'political refrain', adapted from the work of Gilles Deleuze and Felix Guattari, to offer some reflections on the strengths and limitations of protest camps in the action repertoire available to social movements. In the present study, 'camping' was a recurring thematic for British environmental protest, especially in the mobilisations of the Camp for Climate Action. Camps played more than a simple organisational role and signified a desire to prefigure alternative social and ecological configurations. The camp-form, however, took on a logic of its own, locking the protest movement into repertoire dependency, which signified the problematic tension between organisational continuity and tactical innovation. Unable to resolve this tension, and with British climate activism so fundamentally tied to the imaginary of the protest camp, the emergence of a new political praxis was prevented.
\end{abstract}

\section{Introduction}

The security preparations for the London 2012 Olympic Games not only involved 'air security' in the form of surface-to-air missiles stationed on the roof of an East London tower block; organisers also had to reckon with the possibility of protests within the Olympic Park itself. After 
all, there had been recent waves of social unrest and peaceful occupations in the capital, from student demonstrations via the August 2011 riots to Occupy LSX which had encamped outside St. Paul's Cathedral that previous winter. In a bizarre twist, for the purpose of delivering a 'safe and secure' Games, Home Secretary Theresa May thus had 'tents and camping equipment' banned from Olympic venues. The police were advised to deal swiftly 'with anyone who tried to flout the ban' (Home Office, 2012). That tents and camping equipment were explicitly highlighted as potential tools for civil disobedience tells us something about the nature of protest post-Occupy.

The symbolic value of the 'tent' as signifier of some form of 'radical protest desire' is not however universal, the act of camping fulfilling a different organisational role in different instances. This chapter reflects on the tent becoming not only a signifier - a potential weapon of opposition to government policies and national event management in Britain - but a refrain. Whereas the 'tent' may have been a symbol of protest in Occupy and post-Occupy Britain, the 'camp' had played a more vital function in the cycle of struggle that had come before it. Focusing on the Camp for Climate Action in Britain (climate camp hereafter) this chapter argues that 'camping' exceeded its role as either movement repertoire or protest symbol, becoming a central movement refrain that ultimately constrained the possibility of a development in political praxis.

The climate camp was a UK-based environmental direct action network which staged largescale protest camps and actions between 2006 and 2011. Unlike previous protest camps in the UK which had been defensive or reactive in nature, the climate camp consciously set out to choose the time and location of its activity based on its own political agenda in an attempt to break from a previous cycle of 'summit hopping'. The climate camps set out to combine 'highimpact activism with low-impact living' alongside education on the root causes of climate 
change. With an emphasis on the use of horizontal consensus decision-making, these camps strove to embody a commitment to prefigurative politics; the emphasis lay on demonstrating a radical politics in the present rather than waiting for an indeterminate future. Over almost five years, it made headlines, allies and enemies as well as providing a space for developing the skills and politics of many activists who continue to work on climate-related issues or who are now involved in anti-austerity struggles.

Despite the apparent consistency of the organisation, in 2011 the climate camp disbanded itself at the end of a week-long strategy meeting. Contrary to any reading that would suggest this was due to a lack of 'good ideas' or personnel, or the passing into irrelevance of climate change as a political issue, this chapter argues that it was the camp-form itself that foreclosed any development in the organisation's praxis. Utilising Deleuze \& Guattari's (2005) concept of the refrain, it is suggested that the camp-form went from operating as line of flight - a trajectory around which new forces could coalesce - to a straight-jacket of the political imaginary. Drawing on published statements and press releases, as well as extensive militant ethnographic research and our previous research (Russell and Pusey, 2010; Schlembach 2011; Schlembach et al., 2012; Russell, 2014), we hope to illustrate that the camp-form cannot be reduced to either a symbolic gesture nor a protest tool, but must be understood as a complex compositional element that variously enabled and suffocated political opportunity.

Whilst recognising the climate camp as a contested space (Saunders and Price, 2009) for the development of prefigurative politics, solidarities and affects within the broad environmental movement, we want to critically assess its political trajectory and attempts at instigating large scale social change. We want to engage seriously with its central aims and analyse the relationship between these aims and the specific movement repertoire chosen - camping. As protest camps receive a new burst of theoretical attention in the wake of Occupy camps and 
those seen in Southern Europe (Frenzel et al., 2014), it is important that preceding movements which utilised the camp as a political form also receive analysis. The legacy of the climate camps is a mixed one, with some success in participant mobilisation, individual campaigns and 'public pedagogy' (McGregor, 2015) yet ultimately little effect on wider public discourse or systemic change (Bergman, 2015). Whilst its mobilising power, in part based on the vibrant mix of prefigurative and mass direct action strategies (North, 2011), was relatively high in the period of low social struggle in which it operated we hope to highlight the risks a political movement faces of being 'locked' into specific movement repertoires that can take precedence over other considerations.

\section{Situating the climate camps}

In the initial phase of its lifespan, and in the discussions that led to its establishment, climate camp activists made frequent references to their political history and their involvement in the alter-globalisation movements and in environmental direct action (EDA) (Schlembach, 2011). The alter-globalisation movement had its British coming-out party in the summer of 1999 when several action networks came together in the City of London for the 'Carnival against Capitalism'. When the G8 returned to British shores in 2005, to Gleneagles in Scotland, it was met by large scale protest. The Hori-Zone, an explicitly radical 'eco-village', was used as a base camp for the G8's more radical opponents.

While this tapped into an international process of anti-summit events, for many the specific national context was more important. Since the 1990s Britain had seen a wave of environmental direct actions, many of which were launched from protest camps. They had shown opposition to the road-building programme of the Thatcher government at Newbury bypass, delayed the construction of Manchester airport's second runway, and tore up fields of genetically-modified 
crops. Much of this had been under the umbrella label of the Earth First! network (Wall, 1999; Seel and Plows, 2000; Doherty et al., 2003, 2007; Plows et al., 2004). Thus, the Hori-Zone was an expression of the UK EDA movement as well as the G8 summit. It was here that the activists who would begin the climate camp met and began thinking through alternatives to summit hopping and forms of activity which would put climate change firmly on the agenda. From its conception, the camps were thus created at least in part as strategic attempts to break from the calendar of 'counter-summits' that had become a stultifying pattern of the alter-globalisation movement.

With its first manifestation at Drax power station in August 2006 - almost exactly one year after the 2005 anti-G8 protests in Gleneagles - the climate camp needs to be understood not as a separate entity to that which came before, but as a tactical move by some within the alterglobalisation movement to address this perceived shortcoming of the anti-capitalist left. Rather than a separate 'campaign' or 'organisation' emerging with a principle concern of addressing climate change, the climate camp was an outgrowth of the movement, an affirmative attempt to rupture the patterns of counter-summit mobilisations from which it came. Whilst climate change was a concern in its own right, it was its potential to act as a conduit in the reformation of the anti-capitalist movement that led to it becoming a focus for a significant portion of the post-2005 radical left which formed the majority of the initial organising core.

By situating it within the context of ongoing campaigns and previous mobilisations, the important thing to note, then, is that the climate camp did not see itself as a social movement in itself. Rather it was to be regarded as an event or moment in a larger movement going back for decades which was international in outlook (Schlembach, 2011). Some even went so far back as to claim that climate camps were part of a movement of resistance against land enclosures. But in the specific context of the British anti-capitalist movement the climate campers also stood 
in a peculiar relation to the wider British left. In contrast to established coalitions or political parties, the camp organisers rejected the possibility of the network becoming a unified organisation and instead saw their camps as loose convergences of those prepared to use direct action and non-hierarchical decision-making to fight 'the root causes of climate change' (see Plows, 2008; Saunders, 2008, 2012; Mercea, 2013).

This political history is important if we want to understand the forms and practices that gave shape to the first climate camp and created its path dependency for later actions. To name just a few examples, the establishment of regional sub-groups in the camps, dubbed neighbourhoods or barrios, was an idea inspired by popular uprisings in Latin America and had become a popular organisational tool at other European convergences. The use of tripods to hold camping land, here made of scaffolding poles, had been successfully employed in tree defence camps in Australia and anti-roads protests in the UK. The consensus-models of group decision-making and the affinity group system for mass actions referred back to the criticisms of top-down control in political organisation brought by anarchist and feminist activists. In contrast to the Trotskyist organisations which dominated the British radical left, the climate camp was heavily influenced by anarchist perspectives (Frenzel, 2014).

The group's central events were large camps which took place annually from the summer of 2006 until 2010, attracting thousands of participants and significant media interest. Organised around the aims of 'low-impact living, education and high-impact direct action', they functioned as a base for mass direct action against chosen 'targets'. Schlembach et al. (2012, p. 813) described the camps as such: 'An extensive programme of workshops and debates facilitated networking and strategizing, while an impressive logistical operation provided a working example of low-impact and non-hierarchical living.' They finally disbanded in 2011 to 'allow new 
tactics, organizing methods and processes to emerge in this time of whirlwind change' (Camp for Climate Action, 2011).

The first camp was established as a week-long protest not far from the coal-fired power station Drax, Yorkshire, in 2006. Several hundred people assembled to show dissent against an energy policy that was heavily in favour of non-renewable sources, foremost coal. Attempts to 'shut them down' were thwarted by a heavy police presence throughout the week of action, but the camp made international news headlines. Seemingly sanctioned by a scientific consensus that would dictate drastic social and lifestyle changes to limit the negative effects of anthropogenic global warming (Bowman, 2010), the group grew in size and notoriety when, in 2007, it pitched its tents on a squatted field in the vicinity of Heathrow airport, one of Europe's largest aviation hubs. The Heathrow camp saw the first large-scale political disagreement. Some believed that the focus on flying put the emphasis not so much on social change but on individuals' responsibilities to change their consumer behaviours and to 'fly less'. But buoyed by media attention and unprecedented opportunities to 'get our message out there', including on social media (Mercea, 2013), the 2008 camp returned to the issue of energy policy with a protest action at another coal-fired power station, Kingsnorth in Kent.

Throughout the course of their lifecycle, one noticeable effect of the climate camps was the resonance of camping as a form of action and its adoption into the wider radical protest repertoire. Climate camps were held in countries including France, Germany and Australia and these replicated the UK model (see for example Rosewarne et al., 2014). Receiving large media attention climate campers found it difficult to deviate from what appeared to be a successful tactic. As an example, in 2009 British activists mobilised against the G20 summit in London and, under the banner of "G20 Meltdown", held a large protest outside the Bank of England. Alongside this the climate camp organised a day-long 'camp in the city' outside the nearby 
European Climate Exchange in order to focus explicitly on the negative effects of carbon trading. While anti-G20 protesters pushed against police lines to escape a containment cordon that was to keep demonstrators immobile, climate campers attempted to blockade Bishopsgate overnight using pop-up tents. In the event, both sets of protesters were confronted with aggressive public order policing, which tragically resulted in the death of uninvolved bystander Ian Tomlinson (Greer and McLaughlin, 2010; 2012; on the policing of the 2008 and 2009 climate camps, see Baker, 2011).

The final two climate camp events, one on Blackheath Common in South East London and the other on land belonging to the Royal Bank of Scotland's headquarters on the outskirts of Edinburgh, saw increasing attempts at 'soul-searching'. Activists put time aside to discuss the changing nature of the political landscape, after the banking crisis of 2008 had put the spotlight back onto global capitalism. The camp organisers actively invited criticism and fresh perspectives, as long as they were not considered personal gripes or partisan differences. What the camp wanted to discuss were fundamental questions over its direction and strategy, such as its relationship to the state or to workers' organisations. Such strategic questions also included the opportunities and limits offered by the camping refrain.

While the changing political context in which the climate camp was operating led to shifts in its choice of camping sites we can see a clear repetition of form. Each camp tried to achieve the agreed upon aims in roughly the same ways - through a programme of educational events, concrete examples of low impact living and forms of direct action - and there was a strong resemblance between all the camps. Indeed, much of the same equipment was used year after year, stored in organisers' homes or repeatedly borrowed from the 'activist tat collective' - a collective who provide activists with resources such as large marquees. The camp was clearly a reflection of a certain set of political positions and inherited movement repertoires which were 
(re)produced through the education processes at the camp. Part of the education offered at the camps was also practical in nature - it would not be unusual for someone to attend a camp and leave having participated in facilitating a meeting, helping with the cooking, cleaning or waste disposal.

Combined with a decision making structure which emphasises conservative and slow changes, the proliferation of these skills and perspectives helped to replicate the climate camps in the form in which they were begun. British environmental protest camps since then have tended to look very similar as well, for example those staged by 'Reclaim the Power'. The relative homogeneity of climate camps as a form of political activity stands in contrast to the relative difference between Occupy camps. Whereas Occupy's viral spread can be attributed to an easily imitable, yet also customisable, form of action and a political imaginary which captured the public mood in a period of political instability, the climate camp was reliant on slower processes of movement building.

\section{Political tensions}

Despite its easily recountable history, as expressed in a lineage of events, the camp wasn't a homogenous, monolithic structure. The rhythm of annual camps shouldn't be read as evidence of a cohesive and consensual politics. As Saunders and Price (2009) and others have pointed out, the climate camp was a contested political space in which differing perspectives and traditions encountered one another in an attempt to agree the common goals. Although the climate camp has its origins in radical politics, its public visibility as an organisation attempting to engage with climate change and its ethos of openness and participation meant it attracted a wide and diverse range of participants. As well as those who would identify with radical, antiauthoritarian politics various other groupings and political traditions were visibly engaged in the 
process. Some of these groups would less consciously identify with radical political traditions but were mobilised through a concern with climate change in and of itself. As one self-defined liberal camper wrote:

Many people have come into climate camp not from anarchist, anti-capitalist or activist backgrounds, but because they see climate change as a huge threat and climate camp as one of the best ways of trying to stop it. (Camper, 2010)

These various perspectives existed in tension with one another, becoming clearly visible in certain discursive spaces (such as plenaries, workshops, social media and publications) as well as when trying to make decisions. The long term strategy of the climate change movement and the 'solutions' it should be proposing were central sites of political disagreement. Despite the presentation (and common perception) of the climate camps as anarchist in ethos, based on principles of horizontal decision-making and direct action, they were a forum in which the role of the state was fiercely fought over (Schlembach, 2011). Many argued that given the cataclysmic nature of climate change and its time-bounded nature, the climate change movement did not have the time to tackle the wider injustices caused by the state and capitalism. For these participants state-driven and/or market-based solutions would have to be mobilised in the interests of minimising carbon emissions. The planet simply did not have time for radical politics and radicals would have to wait until after the climate crisis to talk about changing economic and political systems of power.

Science was mobilised as a form of expert knowledge in an attempt to bypass these explicitly political disputes (see Bowman, 2010; Schlembach et al., 2012). Research around climatic tipping points helped amplify the power of the apocalyptic imaginary which was being mobilised (Skrimshire, 2008; Swyngedouw, 2010) and campers frequently resorted to the use of science 
to justify what were essentially political choices. Rather than placing the challenge of alternative visions of social organisation in the foreground, the Heathrow camp chose to march behind a banner claiming it was 'armed only with peer reviewed science'.

Perhaps the most visible clash between these perspectives took place between activistorganiser Ewa Jasiewicz and the journalist George Monbiot in the pages of The Guardian newspaper (Monbiot, 2008; Jasiewicz, 2008). Responding to Jasiewicz's argument against state and market-based solutions to the climate crisis Monbiot argued:

She [Jasiewicz] claims to want to stop global warming, but she makes that task 100 times harder by rejecting all state and corporate solutions. It seems to me that what she really wants to do is to create an anarchist utopia, and use climate change as an excuse to engineer it. Stopping runaway climate change must take precedence over every other aim. (Monbiot, 2008)

This led to a backlash from those with a more radical perspective. At the 2008 camp, in response to several workshops and plenaries making these kind of arguments, a 'large group of anti-authoritarian participants' wrote a flyer (Autonomous Anarchist Campers, 2010) arguing that the climate camp 'risk[ed] losing contact with its anti-capitalist and anti-authoritarian roots'.

Hence despite the external appearance of coherence and homogeneity, there was an everpresent set of disagreements and concerns regarding the praxis of the organisation. These long-term political discussions were usually resolved unsatisfactorily with an 'agreement to disagree' or the simple recognition that we 'needed to continue talking about our politics'. This was not due to an organisational hostility to change; attempts were made to respond to these internal tensions, along with the shifting political context precipitated by the financial crisis. 
Camps outside the London carbon trading exchange (2009) or the RBS headquarters (2010) were conscious attempts to respond to these internal and external pressures. Individual campers also became involved in other struggles seeking to bridge the gap between ecological and more traditional workers movement struggles.

Notwithstanding these individual attempts to experiment with the limits of 'confronting the root causes of climate change', the breadth of perspectives within the climate camp failed to materialise any substantial change in the praxis of the organisation. The consistency in the camp's praxis masked an organisation that had an ongoing plurality of forces looking to transform it, and a breadth of critiques which although often welcomed within the organisation's process, were not incorporated into a shift in strategy, function or form. This inertia in political praxis cannot therefore be understood as a result of an unwillingness to change, or a lack of a collective self-awareness of the need to develop different strategies.

\section{Camping as a political refrain}

In the 1988 film Rainman, Tom Cruise plays Charlie Babbit, a narcissistic yuppie with an autodestructive streak fuelled by his own self-aggrandisement. Upon his estranged father's unexpected death, Charlie discovers that he has an older brother Raymond, played by Dustin Hoffman, an autistic-savant with a particular capacity for calculation and a near-instant photographic memory. Following Charlie's kidnap of Raymond from the Walbrook psychiatric institution, the plot develops around the two brothers' relationship as Charlie looks to exploit his older brother's capacity to card-count at Las Vegas casinos. Whilst Cruise's character softens as he becomes used to Raymond's autistic idiosyncrasies, he is ultimately unable to prevent the older brother's return to the psychiatric institution. 
Throughout the film, Raymond Babbit illustrates a number of repetitive tendencies, a common characteristic of autism. These are manifested in routines such as his insistence on purchasing his boxer shorts at a specific K-Mart, his repetition of an Abbot \& Costello sketch 'Who's on First?', and watching his favourite television show Wapner - which he has scheduled to the minute. On the occasions where Raymond is unable to fulfil one of these routines, it leads to an uncontrollable fear and panic until the routine is restored.

Raymond's peculiar little routines exemplify quite dramatically what Felix Guattari called 'ritournelles' - refrains. These refrains are not simply odd characteristics that 'belong' to a specific subject/assemblage, but are rather constitutive of the subject/assemblage itself:

Every individual, every group, every nation is thus 'equipped' with a basic range of incantatory refrains ... They [make] use of [them] to affirm their social identity, their territory, and their internal cohesion; because each member of the group 'belonged' to the same sound-shifter, the refrain thus took on the function of the collective and asignifying subject of the enunciation. (Guattari, 2007, p. 107)

These refrains, gathered and held in consistency with one another, are what constitute an assemblage - they are what define and produce the stable character and content of any given thing. If these refrains become disrupted, it threatens to pull the consistency of the assemblage apart, a return to chaos of the thing. If there is a threat or a disruption to Raymond's refrains there would be 'a mistake in speed, rhythm, or harmony' of Raymond himself - it 'would be catastrophic because it would bring back the forces of chaos, destroying both creator and creation' (Deleuze \& Guattari, 2005, p. 343). The terror that Raymond experiences when faced with a mistake in the rhythm of his refrains is rooted in a direct attack on his existential self, an 
upsetting of the coordinates that define Raymond's capacity to exist in the world. Raymond is his refrains.

As Deleuze \& Guattari outline, the refrain provides a point of order and a circle of control that contribute to the consistency of an assemblage, what makes an assemblage both functional and coherent. Yet at the same time the refrain is something which should allow an assemblage to 'go forth', to connect with other assemblages and to become, such that 'what just a minute ago was a constituted function in the territorial assemblage has become the constituting element of another assemblage, the element of passage to another assemblage' (Deleuze \& Guattari, 2005, p. 357). Raymond provides an image of a malfunctioning assemblage, one in which the body has become completely beholden to the territorialising force of the refrain. Rather than the refrain facilitating the assemblage to go forth - which demands a radical openness to difference - it instead comes to suffocate and restrict the body. The refrain comes to function as a 'black hole', arresting other potentials and preventing the assemblage from entering into processes of becoming.

Rather than the climate camp per se, we can thus trace the 'camping' refrain through a very particular period, perceiving it as both a vector of transformation and asphyxiation of a broader movement. Emerging in the mobilisation against the G8 in Gleneagles, the 'self-sufficient autonomous camp' - itself a complex but generally static assemblage of compost toilets, tents, dietary requirements, sleep patterns or dress codes - assumed the total set of functions of the refrain. It at once provided a point through which to help ground a movement, a territory within which other assemblages could impress on one another, but also a force of deterritorialisation.

At this stage what cohered the assemblage of the alter-globalisation movement was not the camp - which fulfilled a logistical role - but rather the 'act' of the counter-summit. With the 
'movement' having ceased to move, caught in a rhythm of counter-summits that limited potentialities, the 'camp' became a line of flight that ruptured the assemblage of the alterglobalisation movement. What fulfilled a function at Gleneagles became a territorialising force of the Camp for Climate Action.

This tension - between holding on to the initial thrust and knowing when it has become detritus - underpinned the climate camp's existence, and the inability to resolve it was ultimately functional in the organisation's collapse. The demand that we 'discuss our politics' became a mainstay of the monthly or bi-monthly gatherings. This desire was generally quite poorly articulated, and often spiralled into calls for the organisation to make statements regarding its anti-capitalist character. Yet what ran at the core of these calls was a questioning of the very function of the organisation itself - whilst the refrain of the camp had served as an 'element of passage to another assemblage', it was facing the danger of becoming instinctual routine.

The camp form increasingly went from being facilitator to inhibitor, from a space of possibility to a closure of potentials. Across two meetings towards the end of 2008, there was a concerted action by some to bring this question to the table - again couched within the need to 'discuss our politics'. Out of a weekend-long gathering of over 100 people (of which there were eight that year), this introspective review became sidelined to a 10 minute discussion so as to prioritise 'working group' time - the functional groups that ensure the camp was a regular manifestation. Suggestions that it could be possible for the climate camp to explore new avenues for action were rapidly closed down.

The following meeting attempted to extend the discussion, which ultimately became substituted by the need to 'spend less time discussing the issues' and spend more time 'planning actions'. During a further reflection at a national gathering regarding how the organisation should act - on 
what it could do - it was suggested by one participant that "it's not possible for the climate camp to not do a camp - it wouldn't be the climate camp! It's what we do" (personal notes). Whether this intervention was met with sympathy or derision is unclear, but what appeared as a particularly limited perspective on an organisation's capacity can retrospectively be read as an astute account of the assemblage's limits.

As with Raymond Babbit and his repetitive behaviour, there is no sense in looking for an exterior logic or rationale that explains the necessity of the act. The routine manifestation of a camp had become an end in itself, such that the possibility of not camping posed an existential threat to the entire assemblage.

\section{Conclusion: metamorphosis?}

Gathered in a wintery country-house in Dorset for a week-long residential gathering at the beginning of 2011,80 participants in the Camp for Climate Action came to a near-unanimous decision to suspend their collective organising for the coming year. In what ultimately became its final utterance, the organisation released a statement entitled Metamorphosis which suggested that the cessation of activity was 'intended to allow new tactics, organising methods and processes to emerge in this time of whirlwind change'. In lieu of any proposal regarding how the organisation could move forward, it ended itself.

Our thesis has been that the inability of the climate camp to metamorphose - to become something other than what it was - was not due to some circumstantial lack of 'good ideas' or personnel, nor the passing into irrelevance of either climate change or the capitalist arrangement of social relations that drives it. To the contrary, it was the refrain of the camp-form that became the straight-jacket of the political imaginary. What had once provided a trajectory 
around which new forces could coalesce had become a suffocating centripetal force that prevented new political praxis from emerging.

Put simply, acting through anything other than the camp-form posed a threat to the consistency of the organisation. Political possibility itself - which is to say, what could be considered a site of contestation - had become constrained to the point it was necessary to force a catastrophic mistake in the rhythm of the organisation. It was thus with regret that the wintery meeting in Dorset conducted a sort of participatory wavy-hands harakiri, ending the organisation in the name of the principles of the organisation itself - the climate camp is dead, long live the climate camp!

With the climate camp now unlikely to stage any phoenix-like return, what strategic lessons can be drawn from this analysis of 'the camp' as an object of political protest? First and foremost (and perhaps paradoxically), it is not the camp-form itself that deserves particular focus or merit, but rather the context in which it arises; it is the function that proves interesting, not the form. Sitting down on a bus is an occurrence that takes place millions of times a day on every day of the year, yet only one of these instances entered the collective memory of the Civil Rights movement. From a compositional perspective, there is nothing universal to be said about the camp-form, one can only appreciate what role it has played in the past, and dream of what may play that role in the future. As the Camp for Climate Action's final Metamorphosis statement indicates, as contexts change, so will the practices of movements.

As such, the analysis of the camp-form expounded in this chapter can be extended - at least in part - to similar phenomena, such as the role of occuptations in the British student movement (Endnotes, 2013), the party-rave form of Reclaim the Streets (Wall, 1999), or indeed the cycle of summit protests that were central to the alter-globalisation movement. More importantly, the 
analysis is useful not only in assessing movements of the past, but in challenging those who fetishise specific forms rather than interpreting radical social change as both socially contingent and historically specific.

While we have focused on the camp-form, we're not looking to imply that other elements were not at play in the rise and fall of the Camp for Climate Action. Rather, our intention has been to challenge the perception that the 'camp' was simply a tool, a tactic amongst many to be applied by an organisation in pursuit of its goals. To the contrary, as a refrain it had become fundamental to the composition of the assemblage, to the point that if you took away the tent, you took away the organisation. What the climate camp would look like without a tent was a question that ultimately the organisation itself couldn't answer.

\section{References}

Autonomous Anarchist Camper, 2010, An open letter to neighbourhoods, in Shift Magazine and Dysophia (eds) Criticism without critique: a climate camp reader [online] http://dysophia.files.wordpress.com/2010/01/cca reader.pdf.

Baker, D, 2011, A case study of policing responses to Camps of Climate Action: variations, perplexities, and challenges for policing, International Journal of Comparative and Applied Criminal Justice 35, 2, 141-65.

Bergman, N, 2015, Climate camp and public discourse of climate change in the UK, Carbon Management, [online] DOI: 10.1080/17583004.2014.995407. 
Bowman, A, 2010, Are we armed only with peer-reviewed science? The scientization of politics in the radical environmental movement, in S, Skrimshire (ed.) Future ethics: climate change and the apocalyptic imagination, London: Continuum, 173-96.

Camp for Climate Action, 2011, Metamorphosis: a statement from the Camp for Climate Action [online] http://london.indymedia.org/articles/7700.

Camper, A, 2010, Letter from a liberal, in Shift Magazine and Dysophia (eds) Criticism without critique: a climate camp reader [online] http://dysophia.files.wordpress.com/2010/01/cca reader.pdf.

Deleuze, G, 1988, Foucault, Minneapolis: University of Minnesota Press.

Deleuze, G and Guattari, F, 2005, A thousand plateaus, London: Continuum.

Doherty, B, Plows, A and Wall, D, 2003, The preferred way of doing things: the UK direct action movement, Parliamentary Affairs, 56, 4, 669-86.

Doherty, B, Plows, A and Wall, D, 2007, Environmental direct action in Manchester, Oxford and North Wales: a protest event analysis, Environmental Politics, 16, 5, 804-24.

Endnotes, 2013, The Holding Pattern, in Endnotes (eds) Gender, Race, Class and Other Misfortunes, Glasgow: Bell \& Baine, 12-56.

Frenzel, F, 2014, Exit the system? Anarchist organisation in the British climate camps, ephemera, 14, 4, 901-21. 
Frenzel, F, Feigenbaum, A and McCurdy, P, 2014, Protest camps: an emerging field of social movement research, The Sociological Review, 62, 3, 457-74.

Greer, C and McLaughlin, E, 2012, "This is not justice": Ian Tomlinson, institutional failure and the press politics of outrage, British Journal of Criminology, 52, 2, 274-93.

Greer, C and McLaughlin, E, 2010, We predict a riot: public order policing, new media environments and the rise of the citizen journalist, British Journal of Criminology, 50, 6, 104159.

Guattari, F, 2007, The machinic unconscious: essays in schizoanalaysis, New York: Semiotext(e).

Home Office, 2012, Tents banned from Olympic sites, News Story [online] https://www.gov.uk/government/news/tents-banned-from-olympic-sites.

Jasiewicz, E, 2008, Sunday in the camp with George, The Guardian [online] http://www.guardian.co.uk/commentisfree/2008/sep/05/greenpolitics.climatechange.

McGregor, C, 2015, Direct climate action as public pedagogy: the cultural politics of the Camp for Climate Action, Environmental Politics, 24, 3, 342-62.

Monbiot, G, 2008, Climate change is not anarchy's football, The Guardian [online]. http://www.guardian.co.uk/commentisfree/2008/aug/22/climatechange.kingsnorthclimatecamp. 
North, P, 2011, The politics of climate activism in the UK: a social movement analysis, Environment and Planning, 43, 7, 1581-98.

Plows, A, 2008, Towards an analysis of the 'success' of UK green protests, British Politics, 3, 1, 92-109.

Plows, A, Wall, D and Doherty, B, 2004, Covert repertoires: ecotage in the UK, Social Movement Studies, 3, 2, 199-219.

Pusey, A, and Russell, B, 2011, The climate crisis or the crisis of climate politics?, Perspectives on anarchist theory [online] http://www.anarchiststudies.org/node/423.

Rosewarne, S, Goodman, J and Pearse, R, 2014, Climate action upsurge: the ethnography of climate movement politics, Abingdon: Routledge.

Russell, B, 2014, Beyond activism/academia: militant research and the radical climate and climate justice movement(s), Area, [online] DOI: 10.1111/area.12086.

Saunders, C, 2012, Reformism and radicalism in the climate camp in Britain: benign coexistence, tensions and prospects for bridging, Environmental Politics, 21, 5, 829-46.

Saunders, C and Price, S, 2009, One person's eu-topia, another's hell: climate camp as a heterotopia, Environmental Politics, 18, 1, 117-22.

Saunders, C, 2008, Double-edged swords? Collective identity and solidarity in the environmental movement, The British Journal of Sociology, 59, 2, 227-53. 
Schlembach, R, 2011, How do radical climate movements negotiate their environmental and their social agendas? A study of debates within the Camp for Climate Action (UK), Critical Social Policy, 31, 2, 194-215.

Seeds for Change Collective, 2007, How to make decisions by consensus, in Trapese Collective (eds) Do it yourself: a handbook for changing our world, London: Pluto, 63-77.

Seel, B and Plows, A, 2000, Coming live and direct: strategies of Earth First!, in Seel, B, Paterson, M and Doherty, B (eds) Direct action in British environmentalism, London: Routledge, 112-32.

Skrimshire, S, 2008, Approaching the tipping point: climate risks, faith and political action, European Journal of Science and Theology, 4, 2, 9-22.

Swyngedouw, E, 2010, Apocalypse forever? Post-political populism and the spectre of climate change, Theory, Culture \& Society, 27, 2/3, 213-32.

Wall, D. 1999, Earth First and the anti-roads movement, London: Routledge.

Author biography: Bertie Russell has a PhD from the University of Leeds, exploring postpolitics, environmentalism and climate justice activism. His research is focussed on the praxis of 
social change, and the development of our potential for emancipatory transformation. He has published in journals such as Area, City and the Journal for Aesthetics and Protest. Raphael Schlembach is a lecturer in the School of Applied Social Science at the University of Brighton and has published widely on social movement theory, climate action, far right politics and prefigurative protest. He has authored a book called 'Against Old Europe: critical theory and alter-globalization movements' (Ashgate, 2014) and published in journals such as Citizenship Studies, Environmental Politics, Critical Social Policy and Sociology Compass.

Ben Lear is a political organiser and independent researcher based in Manchester. His research interests include social movements, environmental politics and the far right. All three authors have been active participants in the British climate camps. 